\title{
Reye Syndrome Associated with Vaccination with Live Virus Vaccines
}

\author{
An Exploration of Possible Etiologic Relationships
}

David M. Morens, M.D.," Neal A. Halsey, M.D.† Lawrence B. Schonberger, M.D., M.P.H.," Joseph V. Baublis, M.D., Ph.D. $\neq$

\begin{abstract}
To determine whether vaccination with live virus vaccines may be etiologically related to Reye syndrome, we examined 404 cases reported to the Center for Disease Control. Fifteen of 269 children with Reye syndrome had been inoculated with live virus vaccines within 30 days before onset of illness. Although this temporal relationship may have occurred by chance, seasonal distribution and clustering of incubation periods suggests that live virus vaccines may occasionally serwe as cofactors in the etiology of Reye syndrome through andefined mechanisms.
\end{abstract}

\begin{abstract}
A $\mathrm{N}$ instance of Reye syndrome related to administration of live measles vaccine which was reported to the Center for Disease Control (CDC) prompted a search of data on file at CDC for similar cases. This report summarizes our findings.
\end{abstract}

\section{Methods}

Reye syndrome was defined as (1) an acute noninflammatory encephalopathy characterized by cerebrospinal Huid (CSF) containing less than 8 white blood cells (WBC) per $\mathrm{mm}^{3}$ or by histologic sections of brain demonstrating cerebral edema withour meringeal or peri-

\footnotetext{
* Enteric and Neurotropic Disease Branch, Viral Diseases Division, Bureau of Epidemiology, Center for Disease Control, Atlanta, Georgia.

+ Vaccine Evaluation Branch, Immunization Division, Bureau of State Services, Center for Disease Control.

$\$$ Department of Pediatrics, University of Michigan Medical Center, Ann Arbor, M.

Correspondence to: David M. Morens, M.D., Building 7. Room 146, Bureau of Laboratories, Center for Disease Control, Atlanta, GA 30333.
}

vascular inflammation, and (2) evidence of fatty change of the liver demonstrated by biopsy or autopsy, or an SGOT or SGPT 3 times normal or a blood ammonia level 1.5 times normal, with (3) no other explanation for the neurologic or hepatic abnormalities.

We examined report forms of 404 cases of Reye syndrome. These reports had been filed between mid-1971 and December 1976 with either the CDC Viral Diseases Division, Bureau of Epidemiology, which maintains a voluntary nationwide reporting system of Reye syndrome, or with the Immunization Division, Bureau of State Services, to which reports of possible vaccine-related illnesses are sent. Of these tos forms, 269 contained responses to a question about "immunization" [sic] in the previous month.

\section{Results}

Of these 269 children, 23 were stated to have received an "immunization" within one 
TABLE 1. Cases of Reye Syndrome Temporally Associated with Live Virus Vaccination

\begin{tabular}{|c|c|c|c|c|}
\hline Case & $\begin{array}{l}\text { Age } \\
\text { in } \\
\text { Years }\end{array}$ & Vaccine* & $\begin{array}{l}\text { Number of Days Between } \\
\text { Vaccination and Onser } \\
\text { of Prodromal Symptoms }\end{array}$ & $\begin{array}{c}\text { Month of Onset } \\
\text { of Prodromal } \\
\text { Symptoms }\end{array}$ \\
\hline A & 1 & $\mathrm{M}$ & 9 & August \\
\hline$B \S$ & 3 & $\mathrm{M}$ & 10 & December \\
\hline $\mathrm{C}$ & 2 & MMR & 7 & July \\
\hline $\mathrm{D}$ & 6 & $\mathrm{M}$ & 2 & May \\
\hline $\mathbf{E}$ & 1 & MMR & 11 & Ociober \\
\hline$F$ & 12 & $\mathrm{M}$ & 8 & November \\
\hline $\mathrm{G}^{4}$ & 2 & V & 12 & December \\
\hline $\mathrm{H}$ & 2 & V & 10 & November \\
\hline 1 & $5 / 12$ & OPV & 9 & June \\
\hline J & $3 / 12$ & OPV & 8 & June \\
\hline $\mathrm{K}$ & 13 & $-i$ & - & February \\
\hline L & $3 / 12$ & OPV, DPT & $?$ & January \\
\hline $\mathrm{M}$ & $6 / 12$ & OPV, DPT & $?$ & April \\
\hline $\mathrm{N}$ & $3 / 12$ & OPV & 8 & June \\
\hline$O$ & $7 / 12$ & OPV & 10 & January \\
\hline Mean & $3 \neq$ & & & \\
\hline
\end{tabular}

* $\mathrm{M}=$ measles vaccine; $\mathrm{MMR}=$ live measles, mumps, rubella vaccine; $\mathrm{V}=$ vaccinia virus inoculation; $\mathrm{OPV}$ = live oral polio virus vaccine; DTP = diphtheria and tetanus toxoids, and killed pertussis vaccine.

$\dagger$ Not vaccinated, but vaccine-derived polioviruses were

month preceding their illness. Of the 23, four had received bacterial vaccine (diptheria and tetanus toxoids and killed pertussis); three had received an undetermined type of vaccine; and in one the diagnosis of Reye syndrome (measles vaccine-associated) was questionable-the child may have had encephalitis. There were 14 who had been given a live virus vaccine within a month before onset of prodromal symptoms of Reye syndrome; and one other (Case K, Table 1) who had no history of receiving any vaccinations but vaccinederived polioviruses were cultured from him.

Only the 14 children known to have received live virus vaccinations and Case $\mathrm{K}$ are discussed in this survey. These 15 cases were distributed in 11 states and the District of Columbia; they occurred at all times of the year (Table 1).

\section{Representa}

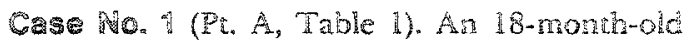
girl was admitted from the emergency room of a small community hospital with progression of fever, vomiting, convulsions, and coma over a 2-day period. She had received live further attenuated measles vaccine 9 days prior to onset of prodromal symptoms, and also rubella vaccine 45 days prior to the onset.

WBC count, CSF analysis, and serum electrolyte levels were within normal limits. While being trans- cultured from patient.

$\$$ Mean for $1974-1976$ for all children, 10.3 years.

$\$$ Previously reported. ${ }^{3}$

"Previously reported. ${ }^{7}$

ferred to a large referral center on the 4th day of illness, she suffered a respiratory arrest and was resuscitated with intravenous urea.

Examination revealed an unconscious child with normal fundi and hyperflexia of both upper extremities. The liver edge was palpated $4 \mathrm{~cm}$ below the right costal margin. Her pupils, which had been fixed and dilated on arrival, responded briskly to light within minutes of the urea infusion.

Laboratory studies included a WBC count of 12,000 with a marked left shift, serum ammonia $0.3 \mathrm{mg} / \mathrm{dl}$ (control, $0.2 \mathrm{mg} / \mathrm{dl}$ ), SGPT 262 units, SGOT 209 units, total bilirubin $0.3 \mathrm{mg} / \mathrm{dl}$, and 2-hour urinary amylase 90 units. Skull films and carotid arteriograms were normal. The electroencephalogram was interpreted as being compatible with Reye syndrome, Grade III on the scale of Aoki and Lombroso. ${ }^{1}$ Liver biopsy studies showed fatty infiltration without significant inflammatory response and electron micrographs revealed swollen mitochondria, both interpreted as consistent with Reye syndrome.

An intracranial pressure monitor ${ }^{2}$ was placed through a burs hole, and intravenous urea administered for repeated "spikes" in intracranial pressure. Her neurologic starus remained poor, however, and at the time of discharge, 66 days later, she suffered from marked spasticity, optic atrophy, and apparent severe intellectual deterioration.

Virologic studies performed at the referral center laboratory included negative cultures of throat, nasopharynx, CSF, rectal swab, urine, and liver tissue. The following indirect immunofluorescent antibody (IFA) studies were negative: screen of the CSF for antibodies to $V-Z$ virus, 
rubella, mumps, and herpes simplex. Serum EB virus titer (IFA) was less than 1:8. Serum rubella titers (IFA) were 1:16 on the 4th, 13th, and 24th days of clinical illness. On the same days, serum rubeola titers (IFA) were $<1: 8,1: 64$, and $1: 32$.

Complement fixation titers of acute and convalescent sera examined by the Michigan Department of Health, Bureau of Disease Control and Laboratory Services, confirmed rubeola seroconversion. There was no evidence of seroconversion to St. Louis Encephalitis virus, LCM virus, herpes simplex, $V-Z$ virus, mumps, parainfluenza 1,2 , and 3 , influenza $A$ and $B$, polioviruses 1, 2, and $3, \mathrm{Myco-}$ plasma pneumoniae, or the LGV agent.

\section{Discussion}

Reye syndrome following vaccination with a live virus has been reported infrequently. Two possible cases of measles vaccine-associated Reye syndrome were described by Landrigan and $W$ itte, ${ }^{3}$ one case of which is included here (Case B, Table 1). The other child did not meet our case definition. Reviews of the Unites States experience with vaccinia virus inoculation by Neff et al..$^{4}$ and Lane $e t a l .{ }^{5}$ revealed no instances of Reye syndrome, although in the earliest of these series marked cerebral edema was noted in all four of the autopsied cases of "postvaccinal encephalitis." In a later series, at least two children had illnesses similar to Reye syndrome. A case of Reye syndrome associated with vaccinederived poliovirus was reported in a 7 -yearold contact by Brunberg and Bell. ${ }^{6}$

Assuming that the inactive components of the vaccines play no role in the etiology of Reye syndrome, there are at least 3 reasonable explanations of the temporal relationship between live virus vaccination and Reye syndrome: (1) It is coincidental. (2) The virus in the vaccine is the sole infectious agent associated with the disease. (3) The virus in the vaccine acts as an etiologic cofactor in conjunction with one or raore other infectious agentes.

When exploring these possibilities, we looked at the prevalence of viral diseases in the communities at the rime of illness. With 6 of the 15 cases, other viruses reported in the past to have preceded Reye syndrome were known to have been recently present, including influenza $B$ in two instances and influenza $A$ in another. Perhaps these or other undetected viruses played a role in the development of Reye syndrome in these patients.
Furthermore, 5 of the 15 children had mild respiratory symptoms preceding the onset of neurologic symptoms; one during the time when influenza $B$ was prevalent in his community. This is suggestive evidence that other etiologic agents may have been involved in at least some of the cases. However, only 3 of the 15 live vaccine-associated cases occurred in the 3-month period (January through March) during which 76 per cent of the Reye syndrome cases reported to CDC in 19741976 occurred, $\mathrm{p}<.0001$, chi-square, Idf, (Table 1).

There was apparent clustering of disease onset in the second week after the vaccination. Prodromal symptoms of Reye syndrome began in 11 instances between 7 and 12 days after the vaccination. If the three cases with unknown vaccination dates are distributed randomly throughout the 30.46 days of the average month, the likelihood of the other 11 cases' clustering within any 7-day period is not great $(p<.01$, binomial expansion). If recall bias were operative, one would expect a more direct relationship between recentness of vaccination and onset of Reye syndrome. Thus, it is difficult to reject the hypothesis that live virus vaccines may serve as cofactors in the occurrence of Reye syndrome, though the available data do not determine whether such a relationship might be secondary solely to primary infection, or to the interaction of the vaccine virus with other infectious agents acquired naturally.

\section{References}

1. Aoki, Y., and Lombroso, C. T.: Prognostic value of electroencephalography in Reye's syndrome. Neurology 23: 333, 1973.

2. Kindt, G. W., Waldman, J., Kohl, S., et al: Intracranial pressure in Reye syndrome. Monitoring and control. JAMA 231: 822, 1975.

3. Landrigan, P. J., and Witte, J. J.: Neurologic disorders following live measles-virus yaccination. JAMA 233: 1459, 1973.

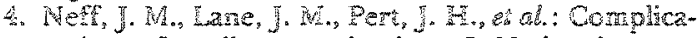
tions of smallpox vaccinations. $\mathbb{1}$. National survey in the United States, 1963. N. Engl. J. Med. 276 : $125,1967$.

5. Lane, J. M., Ruben, E. L., Neff, J. M., et al.: Complications of smallpos vaccination, 1968: National surveillance in the United States. N. Engl. J. Med. 281: 1201,1969 .

6. Brunberg, J. A., and Bell, W. E.: Reye syndrome: An association with type 1 vaccine-like poliovirus. Arch. Neurol. 30: 304, 1974.

7. Roe, C. R., Schonberger, L. B., Gelbach, S. H., et al.: Enzymatic alterations in Reye's syndrome: Prognostic implications. Pediatrics 55: $119,1975$. 